Fedorchenko R. A., Mykhaylenko V. L. Risk factors of cardiovascular disease nowadays. Journal of Education, Health and Sport. 2020;10(4):243-253. eISSN 2391-8306. DOI http://dx.doi.org/10.12775/JEHS.2020.10.04.027

https://apcz.umk.pl/czasopisma/index.php/JEHS/article/view/JEHS.2020.10.04.027

https://zenodo.org/record/3885622

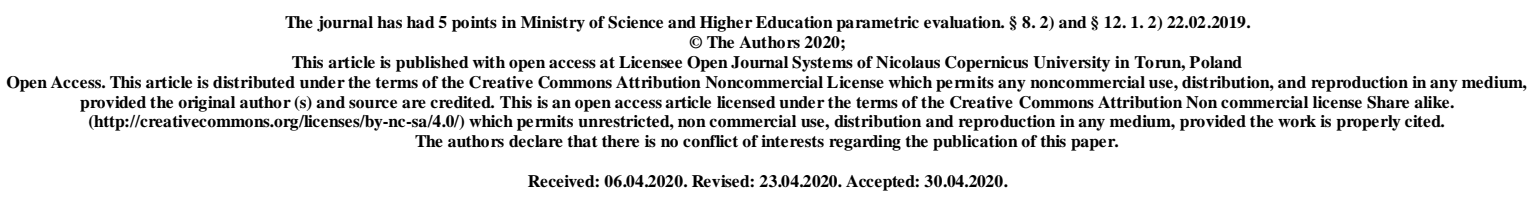

UDC: 616.1-02-07

\title{
RISK FACTORS OF CARDIOVASCULAR DISEASE NOWADAYS
}

\author{
R. A. Fedorchenko', V. L. Mykhaylenko² \\ ${ }^{1}$ Zaporizhzhya State Medical University \\ ${ }^{2}$ Odessa National Medical University
}

Fedorchenko Ruslana A., MD, PhD, Associate Professor of Department of Hygiene and Ecology, Zaporizhzhia State Medical University, Ukraine.

e-mail: ruslanafedorchenko2016@gmail.com

Mykhaylenko Volodymyr L., MD, PhD, Associate Professor of Department of Rehabilitation Medicine, Odessa National Medical University, Odessa, Ukraine

e-mail: vlmykhaylenko@gmail.com

\section{Abstract}

The article analyzes the incidence of the population of Ukraine and the Zaporozhye region by class of diseases of the cardiovascular system, studied the structure and causes of mortality from CVD, cardiovascular disease risk factors.

It is established that the number of adults who have diseases of the cardiovascular system in Ukraine has reached 26,4 million (58\% of the population), more than 400 thousand. people die every year, about 14-15 people out of every 10 thousand adults become disabled. It was found that urban residents of the Zaporozhye region more often than rural (1,3 times, $p$ $<0,05)$ have CVD, and in Melitopol, Zaporozhye, Bilmatsky, Orekhovsky, Veselovsky and Berdyansky districts the incidence rate exceeds the national rate. In V-Belozersky, Zaporozhye, Mikhailovsky, Rozovsky and N-Nikolaevsky areas high levels of morbidity on a hypertensive disease with excess of republican level within $1,5-3,5$ times $(p<0,05)$ are 
registered. The prevalence of coronary heart disease was in line with the national trend, but in 19 districts of the Zaporizhia region the prevalence of strokes was 2,5 times $(p<0,05)$ higher than the Ukrainian average; and in 11 - the prevalence of myocardial infarction exceeded the national level. In the structure of causes of death from CVD, the share of coronary heart disease was $68,9 \%$; cerebrovascular disease $-19,7 \%$, strokes - $8.3 \%$; myocardial infarction (all forms) $-2,5 \%$.

Adverse demographic situation in Ukraine, including Zaporozhye region is largely due to cardiovascular diseases, which significantly affect the main indicators of public health. A stable increase in the general mortality rate and a decrease in life expectancy are of serious concern and indicate the insufficient effectiveness of preventive measures. First of all, preventive measures should be planned in those areas of the Zaporizhzhya region, where the incidence and mortality rates exceed the average regional and republican indicators. These are such cities of Zaporozhye, Melitopol, Energodar and such regions Rozovsky, Tokmack, Zaporizhia and B-Belozersky areas.

Key words: diseases of the cardiovascular system; causes of death; risk factors; prophylaxis.

\title{
ФАКТОРИ РИЗИКУ ХВОРОБ СЕРЦЕВО-СУДИННОЇ СИСТЕМИ В СУЧАСНИХ УМOBAX
}

\author{
Р. А. Федорченко ${ }^{1}$, В. Л. Михайленко ${ }^{2}$ \\ 1Запорізький державний медичний університет \\ ${ }^{2}$ Одеський національний медичний університет
}

Реферат

У статті аналізуються показники захворюваності населення України та Запорізької області на хвороби серцево-судинної системи, структура та причини смертності від них та фактори ризику хвороб ССС.

Встановлено, що кількість дорослих, які мають хвороби серцево-судинної системи в Україні, досягла 26,4 млн (58 \% населення), понад 400 тисяч осіб - щорічно помирають, близько 14-15 осіб із кожних 10 тис. дорослих - стають інвалідами. Встановлено, що міські мешканці Запорізької області в 1,3 рази $(\mathrm{p}<0,05)$ частіше за сільських хворіють на СС3, а рівень захворюваності перевищує республіканський 
показник. Сільські мешканці мають найвищі рівні захворюваності на гіпертонічну хворобу 3 перевищенням республіканського рівня до 3,5 рази $(\mathrm{p}<0,05)$. Розповсюдженість інсультів у 19 районах Запорізької області перевищувала середньоукраїнський показник від 1,5 до 2,5 рази $(\mathrm{p}<0,05)$; а поширеність інфарктів міокарда перевищувала республіканський рівен у 11 районах. У структурі причин смерті від СС3 частка ішемічної хвороби серця становила 68,9\%; цереброваскулярної хвороби - 19,7\%, мозкових інсультів - 8,3\%; інфарктів міокарда (усі форми) - 2,5\%.

Ключові слова: хвороби серцево-судинної системи; причини смертності; фактори ризику; профілактика.

Relevance. Cardiovascular disease poses a real threat to socio-economic well-being throughout the world. It is distributed on various contingents, covering almost the entire geographical territory of South and North America, Europe, Australia, Russia, India and North Africa. The exception is Central and South Africa, where the main problems are HIV infection and tuberculosis, as well as some provinces in China. Atherosclerosis and related cardiovascular diseases, especially coronary heart disease, remain the leading cause of disability in the world, Europe and Ukraine [3]. Coronary heart disease shares first place with diabetes. In addition, recently, cardiovascular diseases in Ukraine occupy a leading place among patients' complaints [9]. According to statistics, diseases of the cardiovascular system hold the lead among the causes of mortality on the planet [4]. They cause 17,000,000 deaths (29\% of the total) annually [4, 8]. In developed countries, mortality from heart disease is declining, but in others it is growing rapidly. Ukraine is among the latter [1, 6. 10].

The purpose and research methods. The aim of the work is to analyze indicators of morbidity and mortality from diseases of the circulatory system in different countries of Europe, the CIS, Ukraine and Zaporizhzhya region, as well as the study of risk factors in the framework of preventive measures.

Bibliosemantic analysis, hygienic, epidemiological, statistical and clinical research methods were used to analyze the state of public health. Mortality was studied according to official forms of state statistical reporting (C-1, C-8) "Mortality by causes of death."

The incidence was considered in accordance with the "International classification of diseases and health problems." For the analysis of the incidence of the population used reporting form 12 "Report on the number of diseases recorded in patients in the service area of the hospitals." 
Research results. The situation in Ukraine is extremely difficult. Annually, more than 400,000 people die (thousands of people daily) from circulatory diseases, about 14-15 people out of every 10 thousand adults become disabled. In 2018, nearly $70 \%$ of deaths were due to circulatory system diseases. From diseases associated with them, more than 387 thousand died in Ukraine and most of all due to atherosclerosis and coronary heart disease [2]. On the second place among the causes of death are oncological diseases, which claimed the lives of 77 thousand people (14\%). Most often, death was recorded from malignant neoplasms of the respiratory system, breast and stomach cancer. More than 30 thousand Ukrainians died as a result of poisoning and other external factors. In addition, 24,000 deaths were due to digestive diseases. The most common among them were liver, pancreas and liver damage from drinking alcohol. In the general structure of the digestive system disease, external and all other causes accounted for $16 \%$ [5].

According to the results of studies conducted by scientists from the Friedrich Schiller University of Jena in Germany, a ranking of countries with the highest mortality from cardiovascular diseases due to malnutrition is compiled. The first and worst place is Ukraine. In general, the top twenty were 14 countries of the former USSR. However, researchers claim that using a balanced diet can prevent approximately one in five premature deaths from cardiovascular disease.

The highest correlation was found between indicators of a high CVD and a diet with a low level of consumption of whole grains, nuts, seeds, vegetables, fruits, legumes, omega-3 fatty acids, as well as with a high level of sodium intake (primarily salt).

In 2018, the share of coronary heart disease in the structure of causes of death from CVD was $68,9 \%$; cerebrovascular disease $-19,7 \%$, cerebral strokes $-8,3 \%$; myocardial infarction (all forms) $-2,5 \%$. Such high rates are not registered in any developed country in the world, and in Europe and America these figures are much lower. The main reasons why heart attacks and strokes began to "reach" Ukrainians aged 35-40 years were poor nutrition, a sedentary lifestyle, stress, and bad habits.

According to the analysis of standardized mortality rates in European countries Germany, Italy, Great Britain, Poland, Romania and Ukraine, it was estimated that the standardized indicator for Ukraine (1010) exceeds the lowest value by 3,5 times that was registered for the UK (288) [4].

In 2018, mortality from diseases of the circulatory system in the Zaporizhzhya region amounted to 1014,7 per 100 thousand people; in Ukraine - 982,0 per 100 thousand people. 
This level of "supermortality" is of particular concern, as it has had unfavorable dynamics over the past 20 years. And this level forms a high percentage of people of working age.

The number of adults with diseases of the circulatory system in Ukraine has reached 26 million people (representing 58\% of the population). 9,5 million of them are people of working age. Very often - in $66 \%$ of patients with coronary artery disease, it is combined with hypertension, in addition, acute and repeated heart attacks account for 55\% of all cases. Up to $60 \%$ of strokes occur against the background of arterial hypertension.

An analysis of the prevalence of circulatory system diseases among the population of Zaporizhzhya region showed that there are differences in levels between rural and urban residents (Table 1). It was established that the average regional level has no significant differences with the republican level, but urban residents are 1,3 times more likely to be sick than rural people $(16337.9 \pm 945.4 / 12628.9 \pm 1126.2$ per 10 thousand, $\mathrm{p}<0,05)$. And in the city of Zaporizhia (16818.6 \pm 829.6 per 10 thousand), B-Belozersky (16203.9 \pm 1720.4 per 10 thousand), K-Dneprovsky (16099.1 \pm 1339.2 in 10 thousand.) districts average levels for the period 2016-2018 exceed the republican rate. The highest incidence rates among the districts of Zaporizhzhya region were recorded among residents of Energodar (8440.5 \pm 804.1 per 10 thousand) and B-Belozersky district (8820.8 \pm 1547.6 per 10 thousand). Moreover, they exceeded the average regional index by 1,4 times $(\mathrm{p}<0,05)$, and the republican level $(5292.4$ per 10 thousand of us.) by 1,7 times $(\mathrm{p}<0,05)$.

Table 1

The prevalence and morbidity of the population of Zaporizhzhya region with circulatory system diseases for 2016-2018

\begin{tabular}{|l|c|c|}
\hline Regions of the Zaporizhzhya & $\begin{array}{c}\text { Prevalence }-\mathrm{M} \pm \mathrm{m} \\
\text { (per 10 thousand) }\end{array}$ & $\begin{array}{c}\text { Incidence } \mathrm{M} \pm \mathrm{m} \\
\text { (per 10 thousand) }\end{array}$ \\
\hline \multicolumn{1}{|c|}{1} & 2 & 3 \\
\hline Zaporizhzhya region & $14917.5 \pm 1006.8$ & $5841.4 \pm 873.7$ \\
\hline Total for cities & $16337.9 \pm 945.4^{* *}$ & $6370.9 \pm 990.7$ \\
\hline Zaporozhye & $16818.6 \pm 829.6^{*}$ & $6319.7 \pm 896.9$ \\
\hline Berdyansk & $14670.2 \pm 1772.1$ & $5998.07 \pm 1494.8$ \\
\hline Melitopol & $15456.3 \pm 1173.6$ & $6173.41 \pm 1185.5$ \\
\hline Energodar & $15807.2 \pm 579.9$ & $8440.53 \pm 804.1^{*}$ \\
\hline Total by districts & $12628.9 \pm 1126.2$ & $4988.4 \pm 710.8$ \\
\hline Yakimivskyi district & $12592.7 \pm 239.2$ & $4998.93 \pm 419.8$ \\
\hline Berdyansk district & $12832.7 \pm 761.4$ & $4507.18 \pm 138.2$ \\
\hline B-Belozersky district & $16203.9 \pm 1720.4^{*}$ & $8820.83 \pm 1547.6^{*}$ \\
\hline Vasilivskyi district & $12016.7 \pm 3452.4$ & $5436.1 \pm 1867.6$ \\
\hline Veselovsky district & $13539.9 \pm 3606.5$ & $4387.2 \pm 2555.4$ \\
\hline Vilnianskyi district & $10708.9 \pm 1080.4$ & $4196.9 \pm 850.7$ \\
\hline G-Pilskyi district & $11697.5 \pm 1091.4$ & $3762.2 \pm 893.1$ \\
\hline
\end{tabular}




\begin{tabular}{|l|c|c|}
\hline \multicolumn{1}{|c|}{1} & 2 & 3 \\
\hline Zaporizhzhya district & $13180.6 \pm 2092.8$ & $6119.9 \pm 1209.7$ \\
\hline Bilmatsky district & $13031.5 \pm 1974.3$ & $4177.9 \pm 1301.2$ \\
\hline K-Dneprovsky district & $16099.1 \pm 1339.2^{*}$ & $6901.4 \pm 517.9$ \\
\hline Melitopol district & $13054.2 \pm 150.6$ & $5481.6 \pm 154.7$ \\
\hline Mikhailovsky district & $11731.1 \pm 378.3$ & $4175.9 \pm 526.8$ \\
\hline N-Nikolaevsky district & $11571.7 \pm 2734.2$ & $4386.1 \pm 2043.4$ \\
\hline Orikhivskyi district & $14595.9 \pm 1009.3$ & $5725.6 \pm 971.2$ \\
\hline Pologovsky district & $10,841.3 \pm 2572.9$ & $3694.9 \pm 1631.9$ \\
\hline Priazovsky district & $9477.9 \pm 2294.1$ & $3867.3 \pm 1418.8$ \\
\hline Primorsky district & $13507.2 \pm 1104.3$ & $5453.6 \pm 613.6$ \\
\hline Rozivsky district & $14679.9 \pm 783.7$ & $6015.1 \pm 910.9$ \\
\hline Tokmak district & $12345.1 \pm 2773.5$ & $4171.8 \pm 1333.7$ \\
\hline Chernihiv district & $11628.8 \pm 2471.5$ & $4467.4 \pm 749.2$ \\
\hline
\end{tabular}

*significant differences were noted between the Zaporizhzhya region and the Ukrainian indicator $(\mathrm{p}<0,05)$

** significant differences in indicators between urban and rural residents $(\mathrm{p}<0,05)$

Particularly noteworthy are the high incidence of hypertension in five districts of Zaporizhzhya region. These are B-Belozersky (413.8 per 10 thousand), Zaporizhzhya (236.6 per 10 thousand), Mikhailovsky (242.3 per 10 thousand), Rozovsky (247.7 per 10 thousand) and N-Nikolaev (237.9 per 10 thousand) districts. The worst situation was in B-Belozersky district, where the indicators exceeded the republican level (200.5 per 10 thousand) by 2,1 times, and the average regional (123.2 per 10 thousand people) - by 3,5 times. But in other areas, excess indicators were within the range of up to 2 times.

The prevalence of coronary heart disease among residents of the Zaporizhzhya region was in line with the all-Ukrainian trend: indicators were at the level of 2220.7 per 10 thousand population. with the exception of metro Melitopol (2555.1 per 10 thousand) and the G-Polsky district (2297.6 per 10 thousand). In these areas, there is a tendency to an increase in incidence. (Fig. 1).

The worst situation was in terms of the prevalence of strokes, which in 19 districts of the Zaporizhzhya region exceeded the average Ukrainian indicator (27.4 per 10 thousand population) from 1.5 to 3 times. However, high levels were recorded in the Rozovsky (61.9 per 10 thousand population), Mikhailovsky (50.9 per 10 thousand population), Tokmack (48.9 per 10 thousand population) districts and in the city of Berdyansk (49.3 per 10 thousand of us.).

An alarming situation also occurs with the prevalence of myocardial infarction (Fig. 2). 


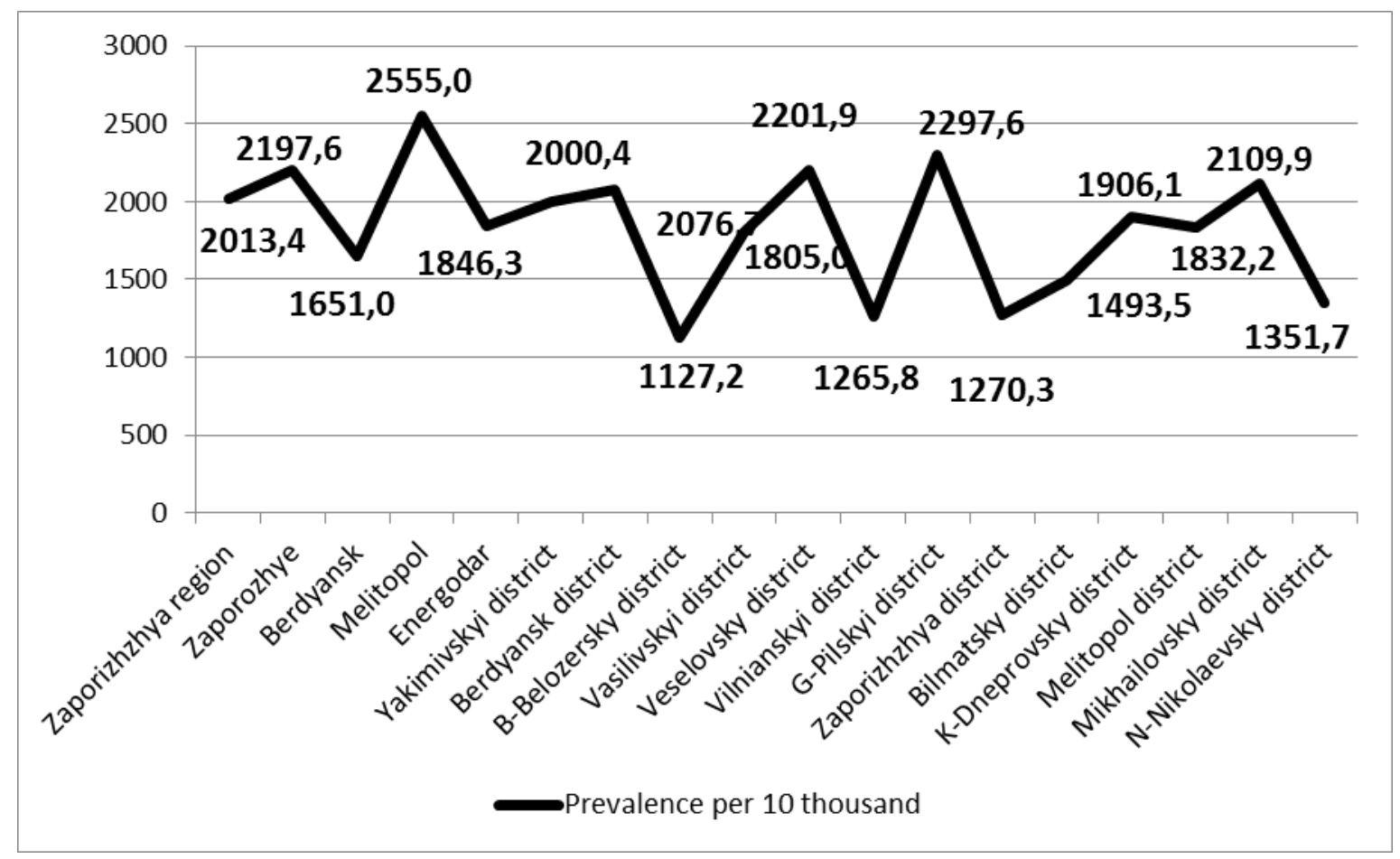

Fig. 1. - The prevalence of coronary heart disease in areas of the Zaporozhye region

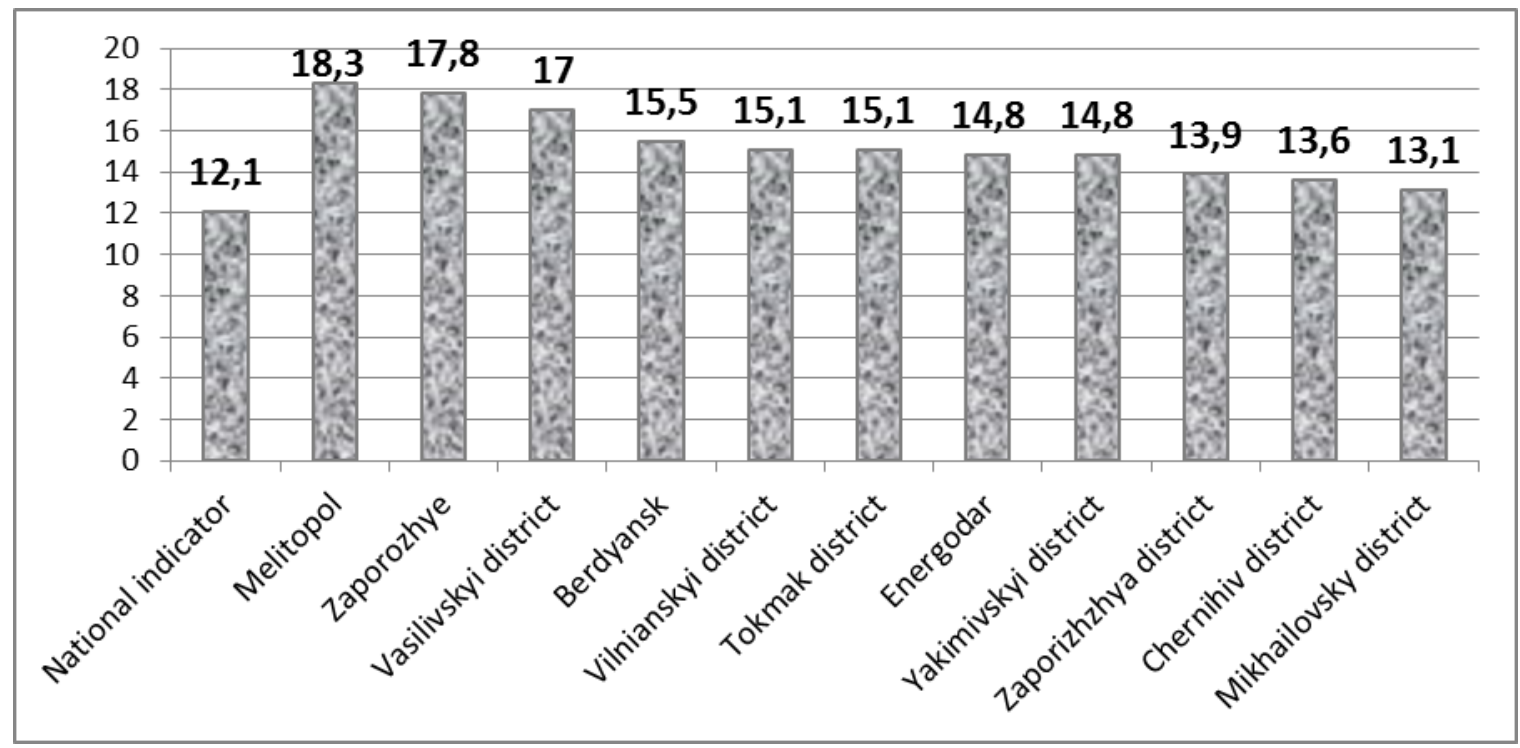

Fig. 2. - The prevalence of acute myocardial infarction among the population of Zaporizhzhya region.

Above the republican (12.1 per 10 thousand population) incidence rates were recorded in 11 districts of the region, but the highest rates were recorded among residents of Melitopol (18.3 per 10 thousand population) and Zaporozhye (17.8 per 10 thousand) . us.), where the excess ratio was 1,5 times. 
The largest number of cases of CVD diseases that are registered for the first time occur in adolescence (16.24 per 1000 children). The indicated pathology for this age cohort of children, together with other factors (obesity, physical inactivity, smoking, chronic foci of infection) in childhood, is the basis for the formation of cardiovascular morbidity in the adult population. In 2014 alone, 11 children died from coronary heart disease (or 0.015 per 10,000 children).

It is impossible not to pay attention to the stressful situations prevailing in Ukraine, mental health disorders (in particular, depression) and their impact on the growth of cardiovascular diseases is an extremely urgent issue. According to the WHO, depression takes the fourth place, and in the future it will belong to water from the first places in the structure of the main causes of disability and mortality in the world, second only to coronary heart disease. The direct effect of post-traumatic stress on the level of overall mortality and mortality from CVD diseases (an increase of 70\%), fatal and non-fatal myocardial infarction (an increase of $30 \%$ ) was established.

According to WHO, the World Heart Federation and the World Organization Against Strokes, $30 \%$ of deaths from heart disease are premature, but $2 / 3$ of such cases can be avoided through primary prevention [7].

The main risk factors for the development of cardiovascular diseases include an increase in blood pressure and blood cholesterol, a sedentary lifestyle, and stress; consumption of large amounts of salt; age over 45 years; male gender; heredity; smoking; diabetes.

Smoking is the most common risk factor among the working population and one of the main causes of cardiovascular disease. The best decision anyone can make for their health is to quit smoking. It has been proven that within 2 years after quitting tobacco, the risk of coronary heart disease is significantly reduced. And after 15 years, the risk of cardiovascular disease is reduced to the level of non-smokers. But you need to remember that passive smoking is also unhealthy.

Regular physical activity reduces the risk of cardiovascular disease. It is recommended that you spend at least 30 minutes of physical activity 5 times a week. This group includes active games, walking, housework, dancing. It is rational to be active daily: for example, you can climb stairs instead of an elevator, take a walk, go on business on a bicycle instead of a car.reas of Zaporizhia region. 
Among the recommendations of specialists, you can increase motivation for playing sports if you involve family and friends in the classes, or download the training application and monitor your progress [11].

Do not ignore issues of self-control weight. Excess weight increases the risk of developing cardiovascular disease. According to our data, arterial hypertension is determined in overweight individuals by almost 3,6 times, and in the presence of obesity $-5,7$ times more often than among people with normal body weight. The age-standardized prevalence rate of overweight is $38 \%$ among men and $22 \%$ among women. With age, regardless of gender, the frequency of this indicator increases. In addition, $17 \%$ of men and $29 \%$ of women living in the city are obese, i.e. weight problems are typical for more than half of the adult population of Ukraine, regardless of gender. Moreover, the prevalence of obesity among women is 2 times higher than in men. It is recommended that you maintain a balanced, healthy diet and consume fewer foods that are high in saturated fat, which can increase your blood cholesterol. It is advisable to eat fish twice a week - this is an excellent source of omega-3 fatty acids, which are very beneficial for the heart. Monitor salt intake. Replace white bread with whole grain bread, cereals from whole grains. Eat plenty of vegetables and fruits. Eliminate or limit the use of alcohol, because alcohol is also high-calorie. Its excessive consumption increases the risk of cardiovascular disease. To maintain their health and life, to prevent various complications of existing diseases of the cardiovascular system, it is necessary to consult a doctor in a timely manner. Even if the heart does not bother, it is important to undergo regular preventive examinations at the family doctor 1-2 times a year.

Thus, preventive measures to combat cardiovascular diseases should cover various levels, starting with the improvement of pediatric, neonatal, cardiological, cardiosurgical care. A separate direction of prevention is the early diagnosis of congenital pathology and chronic diseases. Maintaining registers of children with congenital heart diseases and combating the main risk factors - smoking, poor nutrition, inadequate physical activity, correction of patients' lifestyles and prevention of disease development.

\section{Conclusions}

Adverse demographic situation in Ukraine, including Zaporozhye region is largely due to cardiovascular diseases, which significantly affect the main indicators of public health. A stable increase in the general mortality rate and a decrease in life expectancy are of serious concern and indicate the insufficient effectiveness of preventive measures. First of all, preventive measures should be planned in those areas of the Zaporizhzhya region, where the incidence and mortality rates exceed the average regional and republican indicators. These are 
such cities of Zaporozhye, Melitopol, Energodar and such regions Rozovsky, Tokmack, Zaporizhia and B-Belozersky areas.

We believe that the main directions of the implementation of policies aimed at countering the risk factors of cardiovascular diseases should be:

1. Organization of coordinated intersectoral interaction with all interested parties, awareness and active participation of the public;

2. The practical implementation of the priority of the principle of prevention, improving public awareness of risk factors and the possibilities of preventing their action simultaneously with the creation of conditions by the state for the implementation of the principles of a healthy lifestyle;

3. Organization of timely qualified assistance from medical personnel in reducing the harmful effects of risk factors, promoting the development of a responsible attitude to health.

About $80 \%$ of cases of premature death from heart disease could have been prevented if a systematic fight was made against the main risk factors for CVD diseases, namely, smoking, poor nutrition and inadequate physical activity. Thus, in our opinion, not only government events, but also one's own efforts are the leading factors in health.

\section{Literature}

1. Analiz deiakykh pokaznykiv hromadskoho zdorovia, systemy okhorony zdorovia i medychnoi osvity v Kharkivskii oblasti / O.I. Serdiuk, O.A. Korop, N.V. Prosolenko, V.I. Krupenia ta insh. // Ukraina. Zdorovia natsii. - 2017. - № 3. - S. 227-230.

2. Avhustynovych Ya. I. Suchasni osoblyvosti zakhvoriuvanosti dorosloho naselennia / Ya. I. Avhustynovych // Ukraina. Zdorovia natsii. - 2019. - № 2. - S. 13-20. - Rezhym dostupu: http://nbuv.gov.ua/UJRN/Uzn_2019_2_5.

3. Chepelevska L.A. Tendentsii medyko-demohrafichnykh pokaznykiv Ukrainy u XXI stolitti / L.A. Chepelevska // Ukraina. Zdorovia natsii. - 2018. - № 1. - S. 48-51.

4. Desyat' vedushchih prichin smerti v mire. Centr SMI VOZ // www.who.int/ru/newsroom/fact-sheets/detail/the-top10-causes-of-death.

5. Dudnyk S.V. Tendentsii dynamiky deiakykh demohrafichnykh pokaznykiv za 2014-2016 rr. / S.V. Dudnyk // Ukraina. Zdorovia natsii. - 2017. - № 3. - S. 101-105.

6. Hruzieva T.S. Orhanizatsiia kontroliu za hromadskym zdoroviam u SShA ta krainakh Yevropeiskoho rehionu / T.S. Hruzieva, V.V. Melnyk // Ukraina. Zdorovia natsii. 2015. - № 2. - S. 96-102. 
7. Porivnialnyi analiz pidkhodiv do profilaktyky v Yevropi ta Ukraini / V.M. Lekhan, L.V. Kriachkova, O.P. Maksymenko, M.I. Zaiarskyi [ta insh.] // Ukraina. Zdorovia natsii. 2017. - № 3. - S. 159-164.

8. Ruden V. V. Analiz i prohnoz pokaznykiv smertnosti z prychyny hostroho infarktu miokarda sered naselennia v Ukraini / V. V. Ruden, I. M. Kovalska // Ukraina. Zdorovia natsii. - 2019. - № 1. - S. 131-139. - Rezhym dostupu: http://nbuv.gov.ua/UJRN/Uzn_2019_1_21.

9. Shafranskyi V.V. Stan zdorovia naselennia starshykh vikovykh hrup yak problema systemy hromadskoho zdorovia / V.V. Shafranskyi // Ukraina. Zdorovia natsii. - 2016. - № 4. - S. 38-45.

10. Tsiborovskyi O.M. Determinanty demohrafichnoi sytuatsii v Ukraini / O.M. Tsiborovskyi, L.A. Chepelevska // Ukraina. Zdorovia natsii. - 2017. - № 4. - S. 42-47.

11. Zdorov'e-21: Osnovy politiki dostizheniya zdorov'ya dlya vsekh v Evropejskom regione VOZ: vvedenie // http://www.euro.who.int/_data/assets/pdf_file/0007/109762/EHFA5-R.pdf. 